\title{
Pollutant sources investigation and remedial strategies development for the Kaoping River Basin, Taiwan
}

\author{
C.M. Kao*, F.C. Wu*, K.F. Chen*, T.F. Lin ${ }^{\star \star}$, Y.E. Yen ${ }^{\star \star \star}$ and P.C. Chiang ${ }^{\star \star \star \star}$ \\ * Institute of Environmental Engineering, National Sun Yat-Sen University, Kaohsiung, Chinese Taiwan \\ ** Department of Environmental Engineering, National Cheng Kung University, Chinese Taiwan \\ *** Department of Environmental Engineering, National Lien-Ho College of Technology and Commerce, \\ Chinese Taiwan \\ **** Institute of Environmental Engineering, National Taiwan University, Chinese Taiwan
}

\begin{abstract}
The Kaoping River Basin, located in southern Taiwan, flows through approximately $171 \mathrm{~km}$ and drains towards the South Taiwan Strait. It is the largest and the most intensively used river basin in Taiwan. Based on the results from the pollutant sources investigation and water quality analysis, the main water pollution sources of the Kaoping River were livestock wastewater from hog farms, municipal wastewater, industrial wastewater, leachate from riverbank landfills, and non-point source (NPS) pollutants from agricultural areas in the upper catchment. Concern about the deteriorating condition of the river led the Government of Taiwan to amend the relevant legislation and strengthen the enforcement of the discharge regulations to effectively manage the river and control the pollution. The following remedial strategies have been taken to improve the river water quality since 2001: (1) hog ban in the upper catchment of the Kaoping River Basin, thus, 510 thousand hogs have been removed/relocated; (2) removal of riverbank landfills; (3) enforcement of the industrial wastewater discharge standards; (4) sewer system construction in five cities along the river corridor; (5) application of best management practices for NPS pollutant control; (6) application of natural wastewater treatment systems (e.g. land treatment, constructed wetland, overland flow, riverbank sedimentation/aeration pond) for domestic wastewater treatment in rural areas; and (7) construction of the watershed geographical information system (GIS) and real time water quality monitoring system to effectively monitor and manage the watershed. Recent water quality investigation results indicate that the biochemical oxygen demand (BOD) and nutrient loadings to the Kaoping River have been significantly reduced and the water quality has been improved after the implementation of the remedial strategies described above. Results and experience obtained from this study will be helpful in designing the watershed management strategies for other similar river basins.
\end{abstract}

Keywords BOD; GIS; non-point source pollutant; water quality; watershed management

\section{Introduction}

The Kaoping River basin is the largest and the most intensively used river basin in Taiwan. It is $171 \mathrm{~km}$ long, drains a catchment of more than $3,625 \mathrm{~km}^{2}$, and has a mean flow of 239 $\mathrm{m}^{3} / \mathrm{s}$. Figure 1 shows the Kaoping River, its catchment, and three major reaches (Chi-San Creek, I-Lio Creek, and Lao-Non Creek). It serves as a water supply to Kaohsiung City (the second largest city in Taiwan), several towns, two counties, and a number of large industries (electronic, steel, petrochemical, etc.). Although the mean annual rainfall in this river basin is close to $3,000 \mathrm{~mm}$, over $90 \%$ of it appears in the wet season. The period of high flow rate in the stream usually occurs in the late spring and summer due to the impacts of monsoon and typhoon (Ning et al., 2002). Taiwan Environmental Protection Administration (TEPA) has developed a three-part classification system (Classes A, B, and C) for Kaoping River based on the purpose of water usage and degree of protection for each stream section (TEPA, 1998a). Table 1 presents the water quality criteria for the three classes in Kaoping River. Basically, the upstream is classified as Class A, mid-stream is Class B, and the downstream near the outfall is Class C. Thus, the highest degree of protec- 
tion is given to Class A. Recent water quality analysis by EPA indicates that the Kaoping River is heavily polluted (Ning, 1998; TEPA, 1999; Chiang et al., 2000). The concentrations of some major water quality indicators [e.g., biochemical oxygen demand (BOD), suspended solid (SS), ammonia-nitrogen $\left(\mathrm{NH}_{3}-\mathrm{N}\right)$, total phosphorus (TP), and Escherichia coli] are much higher than the Kaoping River water quality criteria (Chiang et al., 2000). Because of the occurrence of steep slopes in part of the Kaoping River flow courses, higher dissolved oxygen (DO) level is usually observed due to the natural turbulence in the river, which enhances the mass transfer of oxygen between the river and atmosphere (natural reaeration).

The Kaoping River system has a long history of higher BOD, $\mathrm{NH}_{3}-\mathrm{N}$, and TP due to the inadequate disposal of manure from stock farming, industrial effluents, and domestic wastewater discharges; proper utilization of river water as the potable water sources has encountered a new challenge with regards to both technical and managerial requirements. Because of the poor raw water quality, the cost for water treatment has been significantly increased by the Taiwan Water Supply Company in the Kaoping region. However, the quality of drinking water is still questioned and complained about. Concern about the deteriorating conditions of the Kaoping River led the Government of Taiwan to amend the relevant legislation and strengthen the enforcement of the discharge regulations to effectively manage the river and control the pollution. Moreover, some actions have been taken by the Government since 2001 to improve the water quality. The Government also requested the Taiwan Water Supply Company to apply an advanced water treatment system to provide high quality drinking water to the people in the Kaoping River basin. The major objectives of this study were to: (1) investigate and identify the current contributions of point and nonpoint source (NPS) pollutants to the river pollution; (2) select appropriate water quality models for water quality simulation; and (3) evaluate the effectiveness of the applied remedial strategies on water quality improvement.

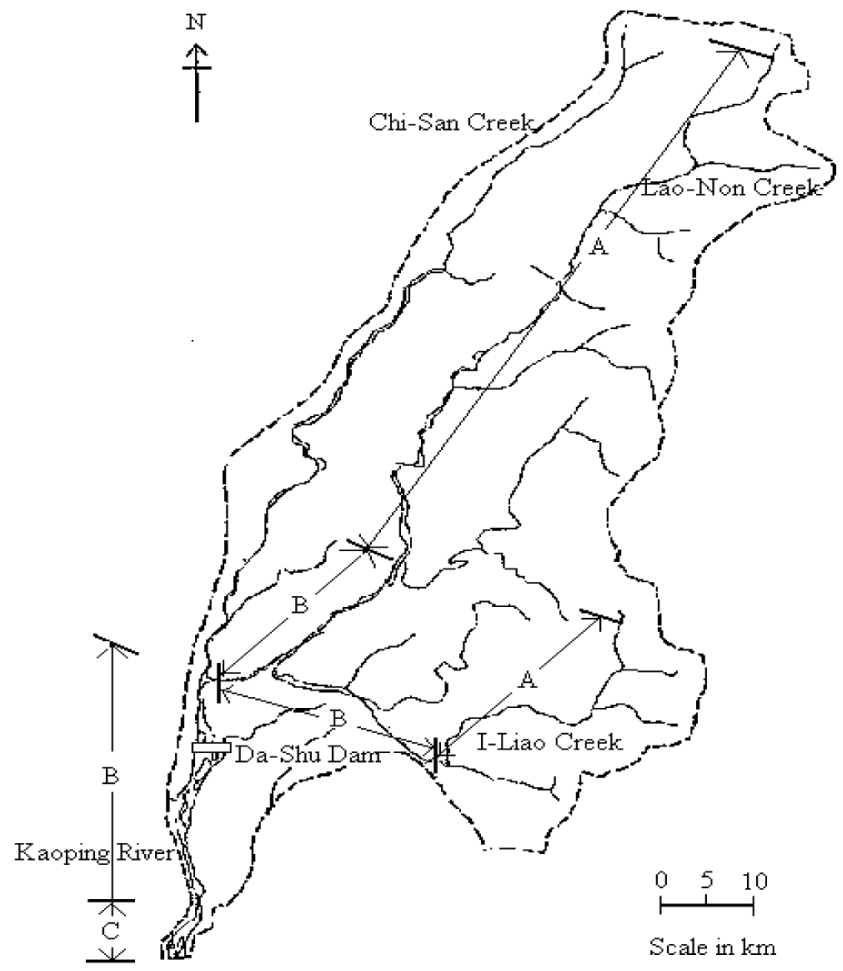


Table 1 Water quality criteria in the Kaoping River

\begin{tabular}{lccc}
\hline Water quality item & $\begin{array}{c}\text { Category A most } \\
\text { upstream reach }\end{array}$ & $\begin{array}{c}\text { Category B most } \\
\text { midstream reach }\end{array}$ & $\begin{array}{c}\text { Category C } \\
\text { downstream reach }\end{array}$ \\
\hline $\mathrm{DO}(\mathrm{mg} / \mathrm{L})$ & $>=6.5$ & $>=5.5$ & $>=4.5$ \\
$\mathrm{BOD}(\mathrm{mg} / \mathrm{L})$ & 1 & 2 & 4 \\
$\mathrm{NH}_{3}-\mathrm{N}(\mathrm{mg} / \mathrm{L})$ & 0.1 & 0.3 & 0.3 \\
$\mathrm{NO}_{3}-\mathrm{N}(\mathrm{mg} / \mathrm{L})$ & 10 & -2 & - \\
Total phosphorus $(\mathrm{mg} / \mathrm{L})$ & 0.02 & 0.05 & - \\
E. coli $(\mathrm{CFU} / 100 \mathrm{~mL})$ & $<50$ & $<5,000$ & $<10,000$ \\
\hline
\end{tabular}

${ }^{1}$ Illustrated in Figure $1 ;{ }^{2}$ no criteria

\section{Pollutant sources investigation}

Results from the pollutant sources investigation demonstrated that both point and NPS pollutants are the causes of BOD, nutrients, and pathogens in the river (Chiang et al., 2000). The main water pollution sources are livestock wastewater from hog farms, municipal wastewater, industrial wastewater, NPS pollutants from agricultural areas, and leachate from abandoned riverbank landfills. Due to the rapid urban and industrial expansion, the percent of sewer system connection in the Kaoping River basin is less than 5\%. Most of the municipal wastewater in the basin (especially in the rural areas) is discharged into the river without proper treatment. The untreated municipal wastewater contributes more than $25 \%$ of the daily BOD loading. Moreover, there are 229 registered industrial factories discharging their wastewater into the Kaoping River. However, it also contains a number of smalland medium-scale industries in the middle and downstream regions. Illegal or expedient discharges are sometimes practised feeding polluted industrial flows into the river. Therefore, the untreated municipal and industrial wastewaters are also two causes of the poor water quality. There are 10 abandoned riverbank landfills within the Kaoping River floodplain. Leachates from those landfills are currently polluting the Kaoping River.

In the Kaoping River basin, most of the upper catchment is used for agricultural activities including cropland and livestock farming. In the upper catchment, NPS pollutants, which are associated with stormwater runoff from agricultural land uses, can be quite diffuse and difficult to treat. Agricultural NPS pollution is considered to be the largest single category resulting in these environmental problems. Nutrients, pesticides, and sediments are the main detrimental NPS constituents. A fast and effective approach for assessing the potential of NPS pollution to assist in the planning of best management practice (BMP) becomes imperative for achieving the goals of a total maximum daily load (TMDL) (Kao et al., 2002; Ning et al., 2002). In this study, geographical information system (GIS) and global positioning system (GPS) were applied to aid in NPS pollutant investigation and analysis. Both GIS and GPS are important means for catchment land-use identification and waste load estimation. Linking the information of land utilization with the NPS pollution simulation model may further provide essential information of pollution potential of NPS pollution for all sub-regions in the river basin.

To approach the goals of water resource conservation, water quality management, and land use effectiveness, the regulation of "Rules of Drinking Water and Source Water Protection Area (DWSWPA) Delineation" was promulgated in 1997. Most of the upper catchment of the Kaoping River Basin has been delineated and identified as the DWSWPA (CPA, 2001). The rules prohibit any developing activities that endanger the quality of the source water within DWSWPA. Thus, no agricultural activities are allowed inside the DWSWPA. However, field investigation results reveal that more than $15 \%$ of the areas located inside the Source Water Protection Zone have been illegally developed into farmlands. Betel palm and orchard farms dominate the illegal farmland areas, and are scattered 
on both sides of the river corridor (CPA, 2001). The total areas of the illegal land-use are estimated to be 2,610 hectares in the Kaoping River DWSWPA (TEPA, 2001). Table 2 presents the illegal land-use patterns identified inside the Kaoping River DWSWPA. NPS pollutants from those illegal land-use would cause the severe contamination of the source water. Investigation results also show that the NPS pollution contributes more than $10 \%$ of the overall pollution loads to the Kaoping River each year (CTC, 1999; TEPA, 2000 and 2001). Thus, NPS pollutants have significant adverse impacts on the river water quality, and should be effectively controlled.

\section{Water quality modeling}

In this study, the Enhanced Stream Water Quality Model (QUAL2E) was selected as the water quality-planning tool to perform the water quality evaluation and watershed management, and the Water Quality Analysis Simulation Program (WASP) model was applied to verify the accuracy of the simulated results (Brown and Barnwell, 1987; Ambrose et al., 1993). The input data for the QUAL2E model include stream segmentation, locations of inflow and outflow, geological and meteorological conditions, hydrological parameters, decay rates, water quality parameters, dispersion coefficient, reaeration coefficient, BOD removal rate, and benthal oxygen demand. WASP is a dynamic compartment model that can simulate the water quality of the water column and underlying benthos for an aquatic system using the finite segmentation method. In WASP, a water body is divided into layers of segments. The time-varying processes of advection, dispersion, point and diffuse mass loading, and boundary exchange are represented in the basic program. Water quality processes are represented in special kinetic subroutines that are either chosen from a library or written by the user. WASP is structured to permit easy substitution of kinetic subroutines into the overall package to form problem-specific models. Both QUAL2E and WASP models can analyze the major water quality parameters. Input parameters for the Kaoping River modeling using those two models are described in CTC (1999), Chiang et al. (2000), and TEPA (2002). In this study, three major water quality parameters ( $\mathrm{DO}, \mathrm{BOD}$, and $\mathrm{NH}_{3}-\mathrm{N}$ ) were selected as the indicators to evaluate the effectiveness of the remedial strategies on Kaoping River water quality improvement.

\section{Development and application of remedial strategies}

Implementation of hog ban and compensation project in DWSWPA and removal of riverbank landfills

To reduce the hog population in the upper catchment of the Kaoping River Basin, the Taiwan Government enforced the hog ban and compensation project in the DWSWPA. By the end of 2001, a total of 510 thousand pigs had been removed/relocated from the DWSWPA. Thus, the manure from hog farming is no longer causing the deterioration of the water quality in the upper stream of the Kaoping River. It is believed that the drinking water quality for 12 million residents in the areas can be effectively improved. Besides the DWSWPA where the prohibition and compensation policies have been implemented, vari-

Table 2 The illegal land-use patterns identified inside the Kaoping River DWSWPA

\begin{tabular}{lcc}
\hline Land-use pattern & Area (hectares) & Percentage \\
\hline Orchard farm & $1,592.1$ & 61 \\
Betel palm farm & 600.3 & 23 \\
Farm land & 313.2 & 12 \\
Recreational area & 78.3 & 3 \\
Others & 26.1 & 1 \\
Total & 2,610 & 100 \\
\hline
\end{tabular}


ous low/zero pollution technology and management strategies have also been promoted in hog farms beside the water source zones. The key solution to resolve the problem is to adjust the basic raising pattern in hog farms. The Government encourages the farmers to incinerate the solid manure for energy recovery, or to compost the manure to generate useful organic fertilizers.

Currently, there are 10 abandoned riverbank landfills within the Kaoping River floodplain. The Government has evaluated the impacts of those landfills on the water quality. Four major riverbank landfills will be cleaned/removed by the end of 2003. The other six landfills will also be removed within five years.

\section{Urban sewer system construction and NPS pollutant control}

Construction of urban sewer systems for five major cities along the Kaoping River corridor are being undertaken to resolve the domestic wastewater pollution problem. The percent of sewer system connection in the Kaoping River basin can be increased from 5\% to more than $15 \%$. Thus, the water quality can be further improved after the completion of the urban sewer systems. The operation manuals of the best management practices (BMP) for NPS pollution prevention and control for the industrial parks, recreational areas, agricultural zones, and construction sites have been edited and published to be used as the basis for NPS control. During the initial stage of implementing the BMP for cropland, extra cost and decreasing harvest may be caused. Thus, the Government would apply the subsidy program to encourage farmers to adopt proper BMP for NPS control.

\section{Enhancing the river environmental quality and construction of natural wastewater treatment systems}

Since 2001, the Government has increased the budget and manpower to clean up the polluted spots along the riverside, and to improve the river ecosystem. Major accomplishments include the provision of highland green areas along the riversides and fishpond ecogarden in the wetlands. Recreational areas are also provided for the general public along several points of the riverside. In the upper catchment and rural areas of the Kaoping River basin, sewer system construction is not applicable. Thus, several natural wastewater treatment systems (e.g. overland flow, constructed wetland, riverbank sedimentation/aeration pond, land treatment) have been constructed for domestic wastewater treatment. Approximately 50 to $60 \%$ of $\mathrm{BOD}$ and $\mathrm{NH}_{3}-\mathrm{N}$ can be removed from the treated domestic wastewater before it is discharged into the Kaoping River.

Other major strategies which have been applied in the basin include the strict enforcement of the site investigation along the riverside, enhancement of water quality in the upstream reservoirs, management of highland wetlands, construction of the watershed GIS and real time water quality monitoring system to effectively monitor and manage the watershed, and enforcement of the industrial wastewater discharge standards. Figure 2 presents the measured and simulated water quality results for $\mathrm{BOD}, \mathrm{DO}$, and $\mathrm{NH}_{3}-\mathrm{N}$ in the Kaoping River from the river mouth $(0 \mathrm{~km})$ to the $84 \mathrm{~km}$ upstream location. Results demonstrate that the simulated data had a good match with the analytical water quality results. The measured results are averaged data in 2002 after the application of the remedial strategies described above. Compared to the water quality results measured in 2000 (Chiang et al., 2000; TEPA, 2001), results in 2002 demonstrate that the water quality has been significantly improved.

\section{Conclusions}

Continuous discharge of industrial organic matter, stock manure, and degradable domestic wastewaters into flowing waters of the Kaoping River system, where most water intakes are located in this region, has resulted in the need of a systematic policy for improving the water quality condition. Both point and non-point source pollutants are the major causes of 

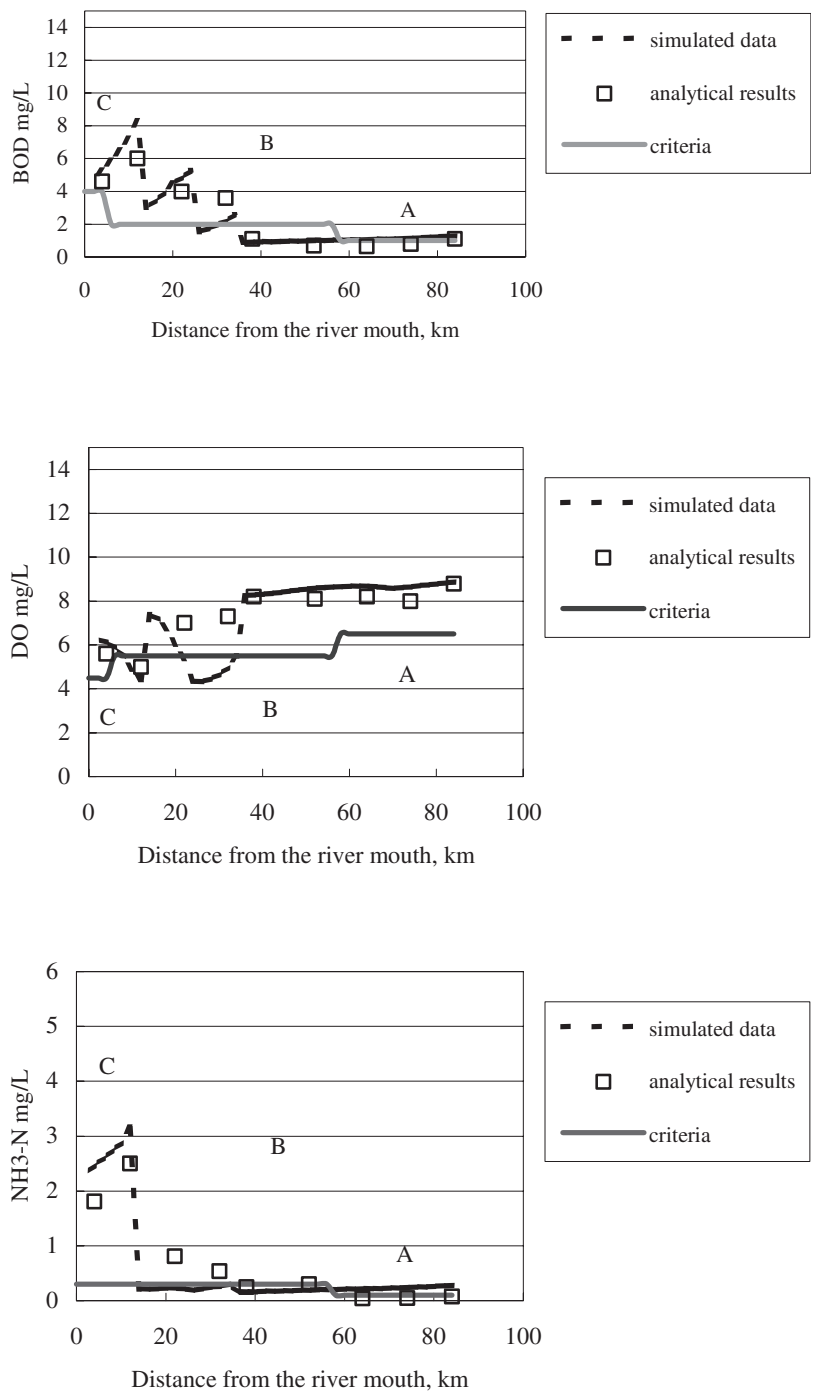

Figure 2 Measured and simulated water quality results $\left(B O D, D O\right.$, and $\left.\mathrm{NH}_{3}-\mathrm{N}\right)$ and three water quality classes (Classes $A, B$, and $C$ ) from the river mouth $(0 \mathrm{~km})$ to the $84 \mathrm{~km}$ upstream location after the application of the remedial strategies

the poor water quality. Thus, improvements of conventional wastewater collection and treatment, as well as reductions in the contaminant loads from point and non-point sources are required to improve the river water quality. A comprehensive remedial strategy for Kaoping River basin management has been undertaken to improve the river water quality since 2001. The strategy consists of short-term management and improvement measures (e.g. riverbank landfills removal, construction of the watershed GIS and real time water quality monitoring systems, application of natural wastewater treatment systems for domestic wastewater treatment in rural areas, enhancing the river environmental quality and creating the recreational spaces), long-term structural measures (e.g. sewer system construction in five cities along the river corridor, application of BMP for NPS pollutant control), and land use management and legislation (e.g. hog ban in the upper catchment of Kaoping River Basin, enforcement of wastewater discharge standards). Recent water quality investigation results indicate that the BOD and nutrient loadings to the Kaoping River have been significantly reduced and the water quality has been effectively improved after 
the implementation of the remedial strategies described above. Results and experience obtained from this study will be helpful in designing the watershed management strategies for other similar river basins.

\section{Acknowledgements}

This study was funded by National Science Council in Taiwan. Additional thanks to Prof. Chang, N.B., Prof. Wen, C.G., and Mr. Ning, S.K. of National Cheng-Kung University, Prof. Kuo, J.T. of National Taiwan University, and Prof. Yu, S.L. of University of Virginia for their assistance throughout this project.

\section{References}

Ambrose, R.B., Wool, T.A. and Martin, J.L. (1993). The Water Quality Analysis Simulation Program, WASP 5: Model Document and Input Database. Environmental Research Laboratory, U.S. EPA, GA, USA.

Brown, L.C. and Barnwell, T.O. (1987). The Enhanced Stream Water Quality Models QUAL2E and QUAL2E-UNCAS: Documentation and User Manual. Report EPA/600/3-87/007, U.S. EPA, Athens, GA, USA.

Chiang, P.C., Kao, C.M., Lin, T.F. and Yan, Y.L. (2000). Sustainable Taiwan 2011. Taiwan National Science Council, Taipei, Taiwan.

CPA, Construction and Planning Administration (2001). Study on Quantitative Criteria of Affecting Factors, Delineation Guidelines, and Performance Indicators for Delineating the Source Water Protection Area of Water Quality and Quantity for Water Supply. Taipei, Taiwan.

CTC, China Technical Consultants, Inc. (1999). Drinking Water Protection Plan in Kaoping River, Report to Kaohsiung County Environmental Protection Agency. Kaohsiung County, Taiwan.

CTC, China Technical Consultants, Inc. (2000). Drinking Water Protection Plan in Ping-Tung County, Report to Ping-Tung County Environmental Protection Agency. Ping-Tung County, Taiwan.

Kao, J.J., Chen, W.J., Ju, C.L., Tsai, C.H., and Lin, W.L. (2002). Analyses of watershed non-point source pollution management strategies. Presented at the IWA Third World Water Congress, April, Melbourne, Australia.

Ning, S.K., Shu, S.Y., Chiang, C.L., Yang, L. and Chang, N.B. (1998). Water quality analysis in Kaoping River basin, The 11th Environmental Planning and Management Conference. Tainan, Taiwan, pp. 216-223.

Ning, S.K., Jeng, K.Y. and Chang, N.B. (2002). Evaluation of non-point sources pollution impacts by integrated 3S information technologies and GWLF modeling. Wat. Sci. Tech., 46(6-7), 217-224.

TEPA, Taiwan Environmental Protection Administration. (1998a). Water Pollution Act, Taipei, Taiwan.

TEPA, Taiwan Environmental Protection Administration (1998b). Investigation and Remediation Planning for Kaoping River and Tung-gan River, EPA-87-G105-03-03, Taipei, Taiwan.

TEPA, Taiwan Environmental Protection Administration (1999). Industrial Wastewater Management Strategy (I). EPA-88-U1G1-03-117, Taipei, Taiwan.

TEPA, Taiwan Environmental Protection Administration (2000). Industrial Wastewater Management Strategy (II). EPA-89-U1G1-03-002, Taipei, Taiwan.

TEPA, Taiwan Environmental Protection Administration (2001). Investigation of Non-point Source Pollution in the Drinking Water source Water Protection Area of Kaoping River Basin. EPA-90-G10302-223, Taipei, Taiwan.

TEPA, Taiwan Environmental Protection Administration (2002). Development of Non-point Source Pollutant Remedial Strategy. EPA-91-G201-01-003, Taipei, Taiwan. 